\title{
The Development of Writing Learning Model Based on the Arces Motivation for Students of Senior High School
}

\author{
ANDREAS KOSASIH, HARIS MUDJIMAN, \\ ST.Y. SLAMET, BUDHI SETIAWAN
}

\begin{abstract}
This research obtains some of the findings which in a word can be described as follows: (1) the step of Introduction (exploration): through study library and observation, it can be found that the quality of writing learning and the need of a better writing learning model, and it is formulated the prototype of writing learning model based on the ARCES motivation,and formulated a prototype-based learning model wrinting motivation ARCES after the draft is validated by the Indonesian language experts and education technology experts. (2) The step of model development: through development of preliminary model and development of main model and after it is done by monitoring, evaluation, focus group discussion and revision, then it is produced a better writing learning model based on ARCES motivation. (3) The step of model effectiveness examination: through pre-test, treatment, and post-test which is produced writing learning model based on ARCES motivation. From the effectiveness test result of model, it can be concluded that writing learning based on ARCES motivation is more effective (in average value of post test is 83,94 ) than writing learning conventionally (in average value of post-test is 75,79 ).
\end{abstract}

Keyword: development of model, writing learning, ARCES motivation.

\section{A. PREFACE}

The lack of teacher's creativity in developing writing learning motivation has caused: (1)the attention of students are unable to arouse, (2) the teaching learning is less relevant with the need of students, (3) students are less of self confidence to follow the teaching learning process, (4) the teaching learning process is not interesting and (5) students are unsatisfied with the teaching learning process. On that account in writing learning a teacher is expected not always restricted to use one theory only. But teacher develops various in using method, media and strategy which can please students, so their motivation will grow and develop and then the result of teaching learning process of Indonesian language can be maximal in cognitive, psychomotor and affective.

Halimah Harun (2006: 96) affirms: "Attitude, interest and motivation play an important role in students' achievement. Therefore, teachers ace well students should developed their attitude, interest and motivation in the teaching and learning process to achieve the target of objectives." Attitude, interest and motivation play an important role in determining an individual attainment phase. To grow attitude, interest and motivation in studying Indonesian language represents the important duty for teachers and students in teaching learning process. Because of motivation is contributor which is very significant to the success of students' study. If students do not do anything like the one ought to be performed by their friends, then it is needed to be investigated the causative. The causative earns all kinds of which the coming can be from teachers, students or environment. The causative which is from teachers is possibility that some teachers are not good enough in giving motivation to students. The cause of students is between one student and other students are very possibly different: the possibility is because of they are poor, lazy, hungry, sick, ashamed, hateful, busy to do other tasks, there are problems with parents or friends and others (Andreas Kosasih, 2003: 32-33).

According to Keller (1987: 5), one of the application and motivation system development is a model: Attention, Relevance, Confidence, and Satisfaction which is shortened with model of ARCS (http://en.wikimedia.org / wiki /motivation.) A teacher in the teaching learning process can apply and develop the principal of this motivation as a mean to stimulate, awaken, increase and look after the students' motivation (Suciati, Prasetya Irawan and Wardani, 1997: 52.) Here, this model can be developed four categories of motivational which need to get attention of teacher in teaching learning process for the agenda of producing an interesting teaching learning and meaningful and gives challenge in formation attitude, behavior and personality of students. In line with that, further Keller in Suciati and Syarifuddin Winatasaputra (1997: 42) arises that a set of motivation principal which can be applied in teaching learning process is called as model of ARCS are: First, Attention, that attention of students will emerge because they are pushed by wanting of knowing. Therefore students' eagerness to know is needed to be stimulated with something new which is different from other which has existed. In other words, the strong learning motivation will be formed if students assume that teaching learning process is attractive. Second, Relevance, that relevant between what will be studied with the need is able to increase the motivation to achievement. Third, Confidence, that feel of self confidence in the form of chance of success will increase achievement motivation. Thereby, in students' self will be arisen the feel of ability to perform or do something. Fourth, Satisfaction, satisfaction because of success will continuously race 
students to reach success in other area. The feel of satisfy which is felt by the students will motivate them to involve actively in teaching learning process.

According to the researcher, all of the motivation principals so-called ARCS is not enough, because this principal is more tend to and dominant till cognitive domain and psychomotor and need to be developed the affective domain sharper. On that account, according to the researcher it is needed to develop the model of ARCS becomes ARCES in teaching learning of Indonesian language, with the hope that the development of this model contains of students' self domain is more tilled in integral and holistic. E element which is intended in ARCES is Enjoyment that is students have happy feeling to the idea in doing activity in teaching learning process.

Basic problem of this research is development of writing learning model based on ARCES motivation for students of senior high school according to Level Curriculum Set of Education (KTSP). The product which is developed in this research is: (1) teaching learning syllabus in writing based on ARCES motivation for students of senior high school, and (2) lesson plan of teaching learning writing based on ARCES motivation for students of senior high school.

Based on the description in the background above in this research can be formulated the problem as follows: (1) How is the implementation of writing learning model now, how is the need level of the improvement of quality of writing learning for students of senior high school, and how is the need of teacher and students related to the improvement of writing learning quality in senior high school? (2) How does the development of learning model prototype become writing learning model based on ARCES motivation for students of senior high school? (3) How is the effectiveness of writing learning model based on ARCES motivation for students of senior high school? Is there any difference of writing competence of students in senior high school which is taught uses learning model based on ARCES motivation and uses conventional learning model? While the purpose of the research is to test the effectiveness of writing learning model based on ARCES motivation (ARCES Based Model of Motivational) for students of senior high school.

\section{B. BASED LITERATURE}

Learning assessment model development based motivation to write this Arces depart from the findings of the relevant scientific research, which is never revealed by previous researchers. Previous research relevant to the study presented as the reference is: (1) Emily Calhoun (1999) under the title: "Teaching Beginning Reading and Writing with the Picture Word Model". The study was designed not only how students can print letters literacy, particularly reading and writing, but also how to listen and pronounce the vocabulary has been developed. Picture word inductive model of combining inductive thinking model and the model of invention concepts so that students can learn the words, sentences, and paragraphs. This model is the core application of highly effective curriculum in kindergarten and elementary school students can learn to read well. Similarly, this model also provides the "safety net" (safety net) for grade elementary, junior high, and high school are still difficult to read and write properly. (2) Andayani (2008) with the title: "Development of Model-Based Learning of Literature Appreciation Quantum Learning in Elementary School". This study concluded that students who take the competency compose literary appreciation of learning with Quantum Learning models better than the students in the conventional learning literature appreciation. This difference is significant, indicating the application of the model in Quantum Learning teaching literature appreciation is more effective than conventional learning literature appreciation in elementary school. (3) Sungkowo Soetopo (2010) with the title: "Model Integrated Learning Indonesian Language and Literature in the Elementary School Quantum Learning Approach". This study offers a model that frees students to learn the language and literature in an integrated manner. With this model, not only the cognitive aspects of students are enhanced, but the affective and psychomotor aspects could be improved. Besides learning with this model, students with a sense of joy can freely express, to create, and produce.

\section{THEORIES}

Theoretical approach in this research includes the things which are related to: definition of the model, definition of research and development, and definition of writing, and ARCES motivation.

1. Definition of the model

Model can be interpreted as an artificial form (replica) from object truthfully, so it have the same form or construction or it looks like the object which is made of its artificial or its example. Model also can be established as a procedural or conceptual example of a program, system, or referable process or guidance for the agenda of solving a problem or reaches a purpose (Sri Sulisyorini, 2007: 13).

2. Definition of Research and Development

Which is intended Research and Development ( R \& D) is a process or steps to develop a new product or makes perfect the existing product and it could be responsible (Nana Syaodih Sukmadinata, 2007: 164). Products 
which are intended can be in the form of object or hardware, like book, module, teaching tools, but it also can be in the form of software, like computer program to process data, program for teaching learning process in class, program for library or laboratory, or educational models, learning strategy, training, tuition, evaluation, management, etcetera (2007: 165).

This research title proposal is: Development of Writing Learning Model Based on ARCES Motivation in Senior High School. Based on the object that is development of learning strategy based on ARCES motivation model as the part of curriculum and process of learning, then this research can be classified into educational research (Sukmadinata, 2005: 23). Methodologically it is closed to the research and development (Gall, Gall, \& Borg, 2003: 123-124). Research and development represents the combination of quantitative and qualitative research. In research, the researcher develops some methods for example: (a) descriptive methods, (b) methods of evaluative and (c) methods of experimental (Nana Syaodih Sukmadinata, 2007).

3. Definition of Writing

Writing is able to be considered as a process and or a result. Writing represents the activity which is performed by someone to produce an article. On that account writing is more comprehended as a skill, not as a science. As a skill, writing needs practices (Puji Santoso, 2008: 6.15).

Writing activity represents a form of ability manifestation and the most recently skill which is mastered by students after listening ability, speaking ability and reading ability. Compared to the three the other abilities, writing ability is more difficult to be mastered (Burhan Nurgiyantoro, 2010: 422). This thing is caused that writing ability wants or requires the acquisition of various language elements to become the content of article. Both of language elements or content element of the message must be arranged in such a manner so that produces article (composition) which is harmonious, solid, and agility. If in speaking activity students must master the sound symbols, writing activity wants students to master visual symbol or the orders of writing, especially which concern on problem of spelling, vocabulary, sentence, and paragraph.

4. ARCES Motivation

About the understanding of motivation, many experts elaborate the opinion based on the point of different emphasis, as according to the result of study which they believe. According to the origin of the word, motivation comes from Latin language movere which means to move. Wlodkowski (1985) in R. Angkowo \& A. Kosasih (2007) explains that motivation is as a condition which causes or generates certain behavior, and which gives direction and resilience (persistence) at the behaviour.

David Mc.Clelland, Abaraham Maslow, Wand and Brown which is cited by Wahyosumidjo (1983), elaborate the understanding of motivation represents a psychological process which expresses interaction between attitude, needs, perception and the decision happened at someone 's self. Motivation is as psychological process arises as a result of factor within someone's self, so-called as intrinsic factor. While extrinsic factor in consequence of outside someone's self.

In the world of education is assorted the motivation theories which can be developed. One of the motivation theories is the model theory of ARCS (ARCS Model). John M. Keller in Reigeluth (1983) compiles a set principal of applicable motivation and developed in process of learning which is in mentioning with model motivation of ARCS (ARCS Models) (Suciati and Udin Syarifuddin Winatasaprutra, 1997: 53). Keller in Driscoll (1994: 314) has a notion that teacher needs to give motivation to students. Or in other words, the emerging of learning motivation in students' self is not merely becoming students' responsibility, but teacher takes charge of also. On that account, motivational principals of ARCS model (ARCS Models) needs to be applied and developed in teaching learning process. Model motivation of ARCS (ARCS Models) can be explained as follows:

a. A = Attention means that learn must have attention and desire about a subject matter. On that account, the eagerness to know needs to get excitement, therefore students will give attention. The attention will be looked after during teaching learning process takes place, or even it will hold up longer again. The eagerness to know can be stimulated through new ways, odd ways, others ways with the ways which has been existing. Attention, according to Keller, can be built through 2 ways (http: // en.wikimedia.org / wiki / motivation) are: (1) generate perception, use something which is not advised to students (tell un-uncertainty) to get attention and the usage of idea, something which surprises, not appropriately and event is not sure. (2) Grow the question which pushes eagerness to know therefore students take attitude to be challenged raising question or problem to be solved by him or her. The atypical ways can stimulate the eagerness to know.

Method which can be developed in teaching learning capable to attract the attention of students among others as follows: (1). Actively participate by the way of for example: use games or plays at by rotation with a purpose to students to involve in seeking of study matters; (2). John M. Keller in Suciati and Udin Syarifuddin (1997: 44) states that strategy to stimulate enthusiasm and attention of students by the way of as follows: (1) Use various learning method. (2) Use media to complete the submission of study material. (3) Use humor if it is required. (4) Use real events to clarify phrased concept. (5) Entangle students. 
b. $\quad \mathrm{R}=$ Relevance (the relevant of = usefulness), it means that learning motivation will grow and develops if students confess that learning materials has direct benefit in themselves. The relevance points to the existence of relation between teaching learning materials with the needs and the condition of students (1997: 45). Strategy to show the relevance among others in the following way: (1) Tell students about what will they get and do after studying the materials. This means that teacher must explain the purpose of the study. (2) Explain about the benefit of the study, skill, value and attitude to be studied, and how the thing can be applied in their future life. (3) Exemplify, practices or tests relate to the condition of students or certain profession.

c. $\quad \mathrm{C}=$ Confidence (self-confidence), it means that it needs to be eliminated doubtfulness in students' self that a certain material cannot be studied by themselves. Strategy which can be developed to grow and develop self-confidence is as follows: (1) Increase hope of students to succeed with multiplying examples of succeeding of students or other figures, by the way of drawing up teaching learning process so that is easy to be comprehended by students by the way of sorting from an easy material to a difficult material. (2) Compile teaching materials into smaller parts, therefore students are not claimed to learn too much new concept all at once. (3) Relate the purpose of study and test criterion or test in the early of study. This thing is performed in a hope that it can assist students to have a clear description about what expected is. (4) Use the success control strategy in students' self. (5) develop self-confidence with words which make the students happy. For example: all of you have comprehended this concept well, however you still have to improve it so that your understanding will be increasing perfectly. (6) Give constructive feedback.

d. $\mathrm{E}=$ Enjoyment (gladness/happiness)

Feel of happy in the activity of teaching learning is determined by the success of learning at time before. Besides the feel of happy is also determined by the result of the analysis of cost-benefit deed learns, and feel of need to learn and confidence that she or he will be able to reach the purpose of learning (Haris Mudjiman, 2008: 91.)

The pleasant teaching learning process shall pay attention to the following things: (1) Comprehend the nature of students. Basically students have characters: eagerness to know something and need the freedom of imagination. Both the characters represent authorized capital for the growth of attitude, creative and critical patterned thinking. The teaching learning process needs to be managed well for the shake of the growth of both the characters. (2) Recognize students individually. The students come from various families and have different abilities. In pleasant learning, individual difference needs to be paid attention to and needs to be mirrored in the teaching learning process. All of students in class do not always do the same activity, but they do different activity according to their learning speed. Students whom have special capability can be utilized to assist their friends who have weak abilities (coeval tutor). By recognizing the ability of students, teachers can assist them if a student gets difficulties, therefore a student can learn maximal.

e. $\quad S=$ Satisfaction, it means that learning must produce feel of satisfy. Because feel of satisfy will support and push the growing of desire to learn. Joyful learning will result of successful learning, or the contrary successful learning will result Joyful learning. The success in reaching a purpose will result satisfaction and students will motivate to go on reaching for the similar purpose. To increase and look after students' motivation, teacher can give strengthening (reinforcement) in the form of praise, giving the opportunity or even if possibly given by present. Strategy to increase satisfaction is: (1) use praise (2) Give feedback. (3) Give opportunity to students to use or practice knowledge which has been obtained. (4) Give opportunity to students who masters to assist their friends who has not mastered. (5) It is good if teacher compares student achievement with teacher achievement with a certain standard.

\section{RESEARCH METHODS}

\section{Types of Research}

Refer to the object, in the development of model to writing, which is part of the learning process and curriculum that are applicable, then this can be category research in to educational research (Sukmadinata, 2005: 23). Other researchers such as Borg and Gall, and Gall, et al, categorize this kind of research as educational and development and abbreviated RD (1983: 772).

\section{Research Procedures}

Development of a model based learning and writing ARCES motivation will be implemented by the research design set out in three strages, as follows, (a) preliminary phase (exploration); (b) stages of model development; (c) model testing stage.

\section{Location Research}

Testing location based writing instructional model selected ARCES motivation is (a) Senior High School State 2 Sragen; (b) Senior High School State 3 Sragen; (c) Senior High School State 1 Tangen; Senior High School State 1 Sambungmacan; (d) Senior High School PGRI Karangmalang; and (e) 
Senior High School Muhammadiyah 1 Sragen, Central Java, Indonesia.

\section{Data Collection Techniques}

Data were collected using an instrument such as check list (check-list) abaut the students writing skills are filled by teachers, as well as instrument such as tests student writing abilities. Tests given prior to treatment (pretest) and after administration of treatment (post-test) with the same material.

5. Data Analysis Techniques

Test Requirements Analysis

a. Normality Test

Changes that will be tested is actually the score of the student ability in writing. Normality test is used to test the data is normal or not. This test is used to test techniques Lilliefors (Lo) at the a = 0,05 significance level (Sudjana, 1996: 446-448). The criteria used is if Lo $<\mathrm{Lt}$, then the data has a normal distibution.

b. Homogeneity Test

Test is used to test the homogeneity of variance in common between two or more groups were compared. To test the homogeneity of variance test was used population Bartlett at significance level $=0,05$ (Sudjana, 1996: 261-263). Testing creteria to be used if the price $\chi 2$ count smaller than $\chi^{2}$ in the table at the significance level $\mathrm{a}=0,05$ which means that the data ar homogeneous.

c. Balance Test

Subsequent to the testing requirements of data analysis. In the next stage which is to compare the value of the dependent variable between groups were determined by the category of an independent variable. This analysis aimed to determine whether there is significance between the groups. Dependent variables than are test scores, while the independent variable is the type of test that categorizes. In this connection it is a type of test in question pretest and posttest. Learning models analyzed are learning to writing conventional (group A), and writing based learning model motivation ARCES (Group B).

Test scores as the dependent variable was measured with a numerical scale. Thus the data analysis methods used were $t$ test (Independent Samples t-test) to compare the two groups on the basis of tests and learning models. ANOVA (one way ANOVA) with one cell line is not the same, to compare the two groups (groups A and B).

\section{Research Output}

The output of this testing phase is a teacher's guide book: "Model-based learning to writing ARCES motivation for high school students" who have tested the process and the product.

\section{E. RESEARCH RESULT}

The third phase from the activity of this research and development is testing the writing learning model effectiveness based on ARCES motivation (ARCES Based on Motivation) which takes sample in six public senior high schools and private senior high schools in Sragen city, that is SMA NEGERI 2 Sragen, SMA Negeri 3 Sragen, SMA Negeri 1 Tangen, SMA Negeri 1 Tangen, and SMA Muhammadiyah 1 Sragen and SMA PGRI Karangmalang. The important features which is suitable to be discussed at the both groups, that is writing learning conventionally (group A), and development of writing learning model based on ARCES motivation (ARCES Based on Motivation) (group B) is as follows:

\section{The Discussion of Writing Learning Conventionally}

In conventional learning teacher does not face any difficulties because teacher does teaching learning process as usual, there is no special things which need to be prepared and studied. Therefore there is no difficulty at all which happened to teacher who teaches by using conventional way. The different activity is only doing pretest and posttest in interval time epoch twelve times face to face meeting. And so do what happen in students' self nor is the special things happened in the process of teaching learning during twelfth times meeting.

Thereby if it is seen from comparison in average value of the effectiveness test of model to the process of writing learning conventionally in the six public senior high schools that is known in average value of pretest 74,9-74,9 and in average value of posttest 75,79. In average value of posttest is higher than values of pretest.

\section{The Discussion of Development of Writing Learning Model Based on ARCES Motivation}

The effectiveness test of model in writing learning aimed to know the effectiveness of learning, with referring to language competence, specifically writing aspects. In the effectiveness test of development of writing learning model based on ARCES motivation can be explained as follows: (a) At the first phase, before doing the teaching learning process, teacher follows the workshop which is held by researcher in Regional Service of Education Office in Sragen, 16 July 2011. At the second phase on 17 September 2011, 
it is held Focus Group Discussion (FGD) in RM ROSO JOYO SRAGEN. Then at the third phase on 15 October it is held Focus Group Discussion (FGD) in RM ROSO JOYO SRAGEN. FGD is held as a mean to make perfect the model that is teacher manual book: development of writing learning model based on ARCES motivation (ARCES Based of Motivation) based on the result of observation, suggestion, input, evaluation from FGD participant, and evaluation and reflection from teachers who conduct main field testing. (b) Teacher studies theories and concepts independently which are offered by researcher deeper. (c) Teacher conducts pretest which is made by researcher. (d) Teacher applies theories and concepts which are offered by researcher in teaching learning process in class. (e) Teacher conducts evaluation and reflection at the end of study. (f) Teacher conducts final test (post-test) after twelve times teaching learning process (12 face to face meetings) by developing writing learning based on ARCES motivation. (g) Teacher explains every result of evaluation and reflection to researcher.

From the result of evaluation and reflection and the result of observation researcher, it can be seen that:

(a) The teachers who teach Indonesian language in class XI are hardly happy, motivated to conduct theory and concept of development of writing learning model based on ARCES motivation and try to apply in teaching learning process.

(b) By developing writing learning model based on ARCES motivation: (1) The attention of students to teaching learning process is increasing; (2) Teaching learning process which is conduct by relevant teacher and appropriate with the need of students; (3) The students' self-confidence is increasing; (4) Students feel happy to learn; (5) Students satisfy with the result of their learning achievement

(c) Students like and enthusiasm in the process of teaching learning which is conducted by teachers, because in teaching learning process there is something new. It is not like the teaching learning before.

(d) By developing writing learning model based on ARCES motivation teachers have more works before teaching, because teachers must really prepare themselves as the hope of the developing ARCES motivation Lesson Plans.

(e) By developing writing learning model based on ARCES motivation students grow and develop, and they like to do the learning activity. Writing learning becomes more efficient and effective and language competence especially writing competence increases / more increasing with comparison indicator in average value of pretest and posttest.

(f) Teaching learning becomes not drags on, vary, and joyful.

From the data above it can be concluded that from the effectiveness test of model as follows: Development of writing learning model based on ARCES motivation (ARCES Based of Motivation) is more effective (in average value of final test 83,94 ) compared to writing learning conventionally (in average value of final test 75,79).

\section{F. THE CLOSSING}

1. The implementation of Indonesian language learning, especially writing aspect for students of senior high school now is very various. The variance is caused by some things, for example: the background of teachers' education, the different experiences of the teachers which influence in choosing a model, selection of material, presentation of material, building motivation, development of method, the use of media and compilation of lesson plans (RPP), understanding of syllabus, the ways in conducting evaluation and the ways to reach the purpose of learning.

2. The development of writing learning model based on ARCES motivation (ARCES Based of Motivation) compiled to entangling the teacher of senior high school, experts and stakeholders through focus group discussion (FGD). FGD is conducted in 3 (three) phases, are: the first phase was in Regional Service of Education Office in Sragen on 16 July 2011; the second phases is in RM ROSO JOYO SRAGEN on 17 September 2011; the third phases was in RM ROSO JOYO SRAGEN on 15 October 2011. FGD is conducted to make perfect the draft of teacher manual book model: development of writing learning model based on ARCES motivation (ARCES Based Model of Motivation) based on: the result of observation, reflection and teacher evaluation and input and suggestion from expert participant and stakeholders.

3. Testing is conducted in two phases are: preliminary field testing and main field testing.

4. The effectiveness testing of writing learning model based on ARCES motivation (ARCES Based of Motivation) conducted in SMAN 1 Sragen with the experiment method. In effectiveness testing test of this model, it is elected two classes from class XI. Class XI IA 5 (group A) as a control group they are given writing learning conventionally. Meanwhile class XI IA 2 (group B) as a treatment group they are also taught with development of writing learning model based on ARCES motivation (ARCES Based of Motivation).

The effectiveness testing result of the model can be concluded that writing learning model based on ARCES motivation (ARCES Based Motivation) is more effective than writing learning conventionally. The conclusion is supported by data of six schools which is the average value of final test (post-test) in the effectiveness testing of 
development of writing learning model based on ARCES motivation is 83,94 it is higher than the average value of final test (post-test) 75,79.

\section{G. BIBLIOGRAPHY}

Burhan Nurgiyantoro. 2010. Penilaian Pembelajaran Bahasa Berbasis Kompetensi. Yogyakarta: BPFE.

Bogdan \& Taylor. 1993. Dasar-dasar Penelitian Kualitatif. Alih Bahasa A. Khosim Affandi. Surabaya: Usaha Nasional.

Borg, Walter. G. Dan M.D. Gall. 1983. Education Research. An Introduction. Fourth Edition.

2001. Teaching by Principles and Interactive Approach to Language Pedagogy. San Francisco State University.

Gall, D Meredith. Joyce P Gall \& Waletr R, Borg. 2003. Educational Research an Introduction. New York: Pearson Publishing.

Hairuddin, dkk. 2007. Pembelajaran Bahasa Indonesia. Jakarta: Direktorat Jenderal Pendidikan Tinggi Departemen Pendidikan Nasional.

Haris Mudjiman. 2011. Belajar Mandiri. Surakarta: UPT Penerbitan dan Percetakan UNS (UNS Press) dan Lembaga Pengembangan Pendidikan (LPP) UNS.

Keller, JM. 1987. Development and Use of The ARCS Models of Motivational Design. J. Instr. Dev. New Jersey.

Kosasih, A. 2003. Pengaruh Penggunaan Media Gambar dan Motivasi Belajar Terhadap Kepribaian Siswa pada Pendidikan Budi Pekerti. (Tesis) Surakarta: Program Studi Teknologi Pendidikan Program Pasca Sarjana Universitas Sebelas Maret.

\& Angkowo, R. 2007. Optimalisasi Media Pembelajaran. Jakarta: Grasindo.

Nana Syaodih Sukmadinata. 2007. Metode Penelitian Pendidikan. Bandung: Program Pascasarjana Universitas Pendidikan Indonesia dengen PT Remaja Rosdakarya.

Oemar Hamalik. 2008. Proses Belajar Mengajar. Jakarta: Bumi Aksara.

Sri Sulisyorini, 2007. Model Pembelajaran IPA Sekolah Dasar. Semarang: Fakultas Ilmu Pendidikan, Jurusan Pendidikan Guru Sekolah Dasar Universitas Negeri Semarang (UNNES) dengan Tiara Wacana.

Suciwati, Prasetya Irawan \& Wardani. 1997. Teori Belajar, Motivasi dan Ketrampilan Mengajar. Jakarta: PAUPPAI. DIRJEN DIKTI.

dan Udin Syarifuddin. 1997. Teori Motivasi dan Penerapannya dalam Proses Belajar Mengajar. Jakarta: Dikti.

Wahyosumidjo. 1987. Kepemimpinan dan Motivasi. Jakarta: Ghalia Indonesia.

*Andreas Kosasih

E-mail:kosas_ih@yahoo.com

Student of Doctoral Program, Indonesian Language Education Sebelas Maret University, Surakarta, Indonesia.

*Haris Mudjiman,

Professor of Sebelas Maret University, Surakarta, Indonesia.

*St. Y. Slamet,

Professor of Sebelas Maret University, Surakarta, Indonesia.

*Budhi Setiawan

Lecturer Sebelas Maret University, Surakarta, Indonesia. 
This academic article was published by The International Institute for Science, Technology and Education (IISTE). The IISTE is a pioneer in the Open Access Publishing service based in the U.S. and Europe. The aim of the institute is Accelerating Global Knowledge Sharing.

More information about the publisher can be found in the IISTE's homepage: http://www.iiste.org

\section{CALL FOR PAPERS}

The IISTE is currently hosting more than 30 peer-reviewed academic journals and collaborating with academic institutions around the world. There's no deadline for submission. Prospective authors of IISTE journals can find the submission instruction on the following page: http://www.iiste.org/Journals/

The IISTE editorial team promises to the review and publish all the qualified submissions in a fast manner. All the journals articles are available online to the readers all over the world without financial, legal, or technical barriers other than those inseparable from gaining access to the internet itself. Printed version of the journals is also available upon request of readers and authors.

\section{IISTE Knowledge Sharing Partners}

EBSCO, Index Copernicus, Ulrich's Periodicals Directory, JournalTOCS, PKP Open Archives Harvester, Bielefeld Academic Search Engine, Elektronische Zeitschriftenbibliothek EZB, Open J-Gate, OCLC WorldCat, Universe Digtial Library, NewJour, Google Scholar

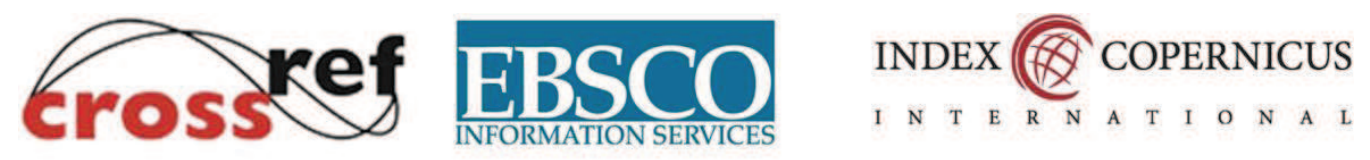

\section{(D) ULRICHSWEB}

JournalTOCs

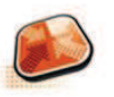

PKP | PUBLIC KNOWLEDGE PROJECT
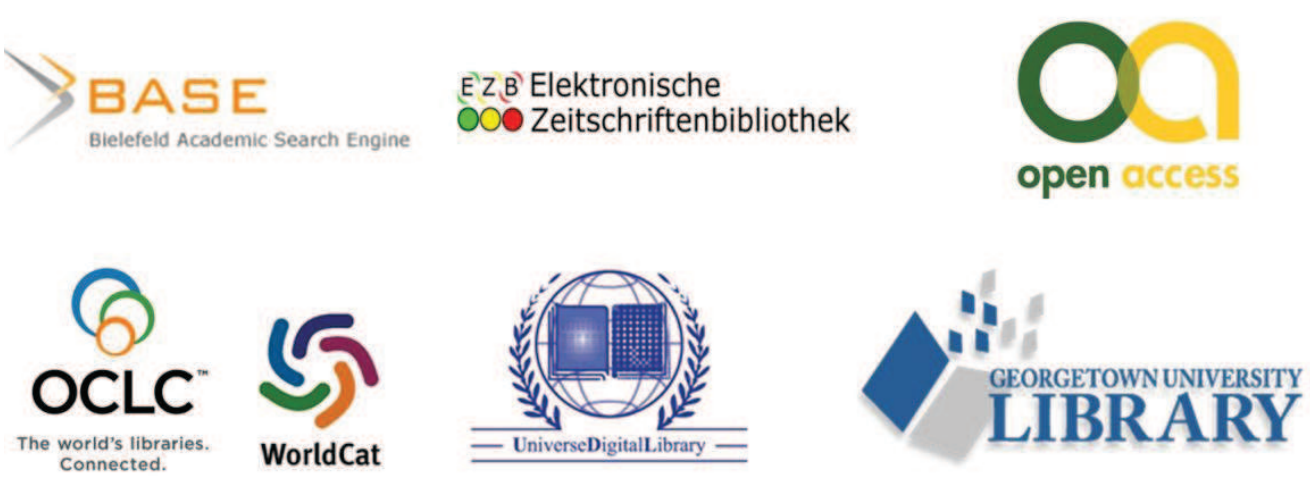